\title{
Recovery of the macrobenthic community in the Valli di Comacchio, northern Adriatic Sea, Italy
}

\section{Restauration de la communauté macrobenthique des Valli di Comachio, au nord de l'Adriatique, Italie}

\author{
Cristina Munari ${ }^{\text {a }}$, Simone Modugno ${ }^{\text {a }}$, Francesco Ghion ${ }^{\text {b }}$, Giuseppe Castaldelli ${ }^{\text {a }}$, \\ Elisa Anna Fano a, Remigio Rossi ${ }^{\text {a }}$, Michele Mistri ${ }^{\text {a,* }}$ \\ ${ }^{a}$ Department of Biology, University of Ferrara, via L. Borsari 46, 44100 Ferrara, Italy \\ ${ }^{b}$ A.R.P.A., C.so Giovecca 169, 44100 Ferrara, Italy
}

Received 31 July 2002; accepted 30 September 2002

\begin{abstract}
The macrobenthic community structure of the Valli di Comacchio (northern Italy) was described in order to assess the ecological conditions of the main basins through 2001. In addition, the biotic data set gathered in 1997-1998 was compared to achieve an estimation of the eventual recovery of the lagoonal benthic assemblages. Four permanent sites (P1, M4, M5 and M6), located along a gradient of sediment texture and confinement, and representing four different areas of the lagoon, were sampled quarterly in 2001 for macrofauna and sedimentary variables (organic content, phytobenthic chlorophyll-a, depth of the redox potential discontinuity layer), and fortnightly for water variables (temperature, salinity, dissolved oxygen and planktonic chlorophyll-a). Water and sedimentary variables were typical of eutrophic areas. A total of 52 macrobenthic taxa were identified and, on the basis of the species collected, differences in faunal distribution among the four areas were recognized, although less marked than in previous studies. Sediment trophic status and its seasonal dynamics in the Valli were crucial in determining species distribution among the different areas. The comparison between 1997-1998 and 2001 biotic data indicated that conditions in the lagoon had improved, especially in the formerly most impaired, central area. In the Valli di Comacchio, the recovery of benthic communities after severe disturbance will probably take longer, even if sewage discharges have been removed 11 years ago. Secondary disturbance due to scarce water circulation, sharp temperature and salinity fluctuations, release of toxic substances from sediments influenced animal assemblages along spatial and temporal scales. The interplay of these variables probably caused deviations from the expected improvement in benthic conditions. Nevertheless, clear signs of amelioration, particularly at the previously most impaired area, were detectable.
\end{abstract}

(C) 2003 Éditions scientifiques et médicales Elsevier SAS and Ifremer/CNRS/IRD. All rights reserved.

\section{Résumé}

La structure de la communauté macrobenthique des Valli di Comachio est décrite pour définir les conditions écologiques des principaux bassins en 2001. Ces données sont comparées à celles de 1997-1998 pour mettre éventuellement en lumière une restauration de cet écosystème. Quatre stations permanentes localisées selon un gradient de texture sédimentaire et de confinement et représentant quatre aires différentes du système lagunaire ont été échantillonnées. Les mesures ont été effectuées chaque trimestre pour la macrofaune et le sédiment (contenu organique, chlorophylle $a$ du phytobenthos, couche de discontinuité du potentiel redox) et chaque quinzaine pour la masse d'eau (température, salinité, oxygène dissous et chlorophylle $a$ planctonique). Toutes ces variables sont caractéristiques d'aires eutrophes. Un total de 52 taxons a été identifié pour le macrobenthos. Des différences apparaissent entre les quatre zones quoique moins marquées que lors d'études précédentes. L'état trophique du sédiment et la dynamique saisonnière constituent des variables cruciales pour la distribution des espèces. Les conditions dans la lagune se sont améliorées depuis 1997-1998, particulièrement dans la zone centrale. Dans les Valli di Comachio, la restauration des communautés benthiques après une perturbation sévère demandera du temps, même si la décharge des effluents

\footnotetext{
* Corresponding author.

E-mail address: m.mistri@unife.it (M. Mistri).
} 
a été arrêtée il y a onze ans. Une perturbation secondaire due à la faiblesse de la circulation, aux variations brusques de température et de salinité et à l'apport de substances toxiques originaires du sédiment influence les communautés animales. Les interactions entre ces facteurs expliquent les déviations par rapport à la restauration espérée des conditions benthiques. Cependant, des signes clairs d'amélioration apparaissent, particulièrement dans la zone préalablement la plus altérée.

(C) 2003 Éditions scientifiques et médicales Elsevier SAS and Ifremer/CNRS/IRD. Tous droits réservés.

Keywords: Macrobenthos; Valli; Adriatic Sea; Recovery

Mots clés : Macrobenthos ; Valli ; Mer Adriatique ; Restauration

\section{Introduction}

During recent decades, environmental conditions have deteriorated in the Valli di Comacchio, the largest lagoonal system in the Po River deltaic area (northern Italy). This shallow-water ecosystem underwent important anthropogenic impacts, from land reclamation to the effects of contamination on the remaining areas. Such conditions were further exacerbated, up to a decade ago, by high organic enrichment resulting from sewage discharge from intensive fish farming activities. This lead to the collapse of the lagoon, with a drastic depletion of all planktonic and benthic components, and the dominance of pycocianobacteria (Sorokin et al., 1996). Nowadays, the Valli are characterized by such hydrologic and physical-chemical conditions (shallow water with long residence time, eutrophic marine influence and inputs of nutrient-rich continental waters, anoxic sediment layers with production of sulfides) to be considered a very harsh environment (Mistri et al., 2000). Earlier studies, however, reported a high number of macrobenthic species at the beginning of the 1970 s, on account of the elevated heterogeneity of the habitats and the large area of marine phanerogams (Colombo et al., 1977). Given the economic and naturalistic importance of the lagoon, a monitoring program was initiated in 1996, after the failure and subsequent closure of aquaculture activities. The aim was to check the environmental condition of the main basins, and to allow estimation of the potential, and the time needed, for recovery of the Valli, by focusing the analysis on macrobenthic community patterns. Infaunal communities are probably the best tools to describe the ecological conditions of aquatic ecosystems, since they are in intimate contact with sediments, which accumulate the multiple sources of organic enrichment and pollution (Le Bris and Glémarec, 1996). Preliminary results highlighted the resistance to change of community functioning (Mistri et al., 2001) despite stresses that generate quite unpredictable abundance fluctuations (Mistri, 2002a), as well as the role played by local disturbance events in structuring communities (Mistri et al., 2002).

The aim of the present study was to describe the macrobenthic community structure in order to assess the ecological conditions in 2001, about ten years after the end of aquaculture plants. In addition, the 1997-1998 (Mistri et al., 2000) and 2001 data of benthic assemblages were compared, to achieve estimation of the recovery of the lagoon. Since the monitoring program was carried out in the same areas of the lagoon and with the same sampling strategy, it provides an appropriate basis for comparison.

\section{Materials and methods}

The Valli di Comacchio is a semi-enclosed lagoonal complex of about $100 \mathrm{~km}^{2}$, with an average depth of $1 \mathrm{~m}$, almost completely surrounded by earthen dikes, and separated from the sea by the highly anthropogenically impacted, $2.5-\mathrm{km}-$ wide Spina spit. Four permanent sampling stations, located along a gradient of sediment texture and confinement (sensu Guelorget and Perthuisot (1983), i.e. the turnover time of marine waters), were sampled in 2001 Fig. 1. Stations M4 (1.2 m depth) and P1 (1.1 m depth) were located in areas subjected to the inflow of marine and riverine waters, with P1 more confined with respect to M4. M6 (1.2 m depth) was in the central area of the lagoon, near the old effluent pipe of aquaculture plants; this site was the most confined, being far from marine or riverine water inputs, but in January 2001 the unused Bellocchio drain was enlarged and became operative. M5 (0.9 m depth), finally, was in the southernmost part of the lagoon, in an area characterized by the presence of a scarce bed of Ruppia cirrhosa and by occasional freshwater inflows from the Reno River through a dam. These four stations were previously comprised in a wider monitoring program, which included 12 sampling sites (Mistri et al., 2000), and being highly representative of the different ecological conditions found in the Valli, were chosen as long-term monitoring stations. The 2001 macrobenthic community structure was studied by collecting samples in triplicate at each site in January, March, July and October. The abundance of individuals, identified at the species level when possible, was measured for each sample. Changes in macrobenthic community structure and composition were also investigated by comparing the 2001 with the 1997-1998 data set (sampling dates: November 1997, March, June, and September 1998; Mistri et al., 2000. Sampling and sorting techniques are fully described elsewhere (Mistri et al., 2000, 2002).

Sediment cores were also collected in triplicate on the same four sampling dates at each site (with the exception of October at P1 because of technical constraints), and the first $5 \mathrm{~mm}$ were analyzed for total organic content (loss of weight on ignition at $500{ }^{\circ} \mathrm{C}$ ), and microphytobenthic chlorophyll-a (Lorenzen and Jeffrey, 1980). Depth of the redox potential 


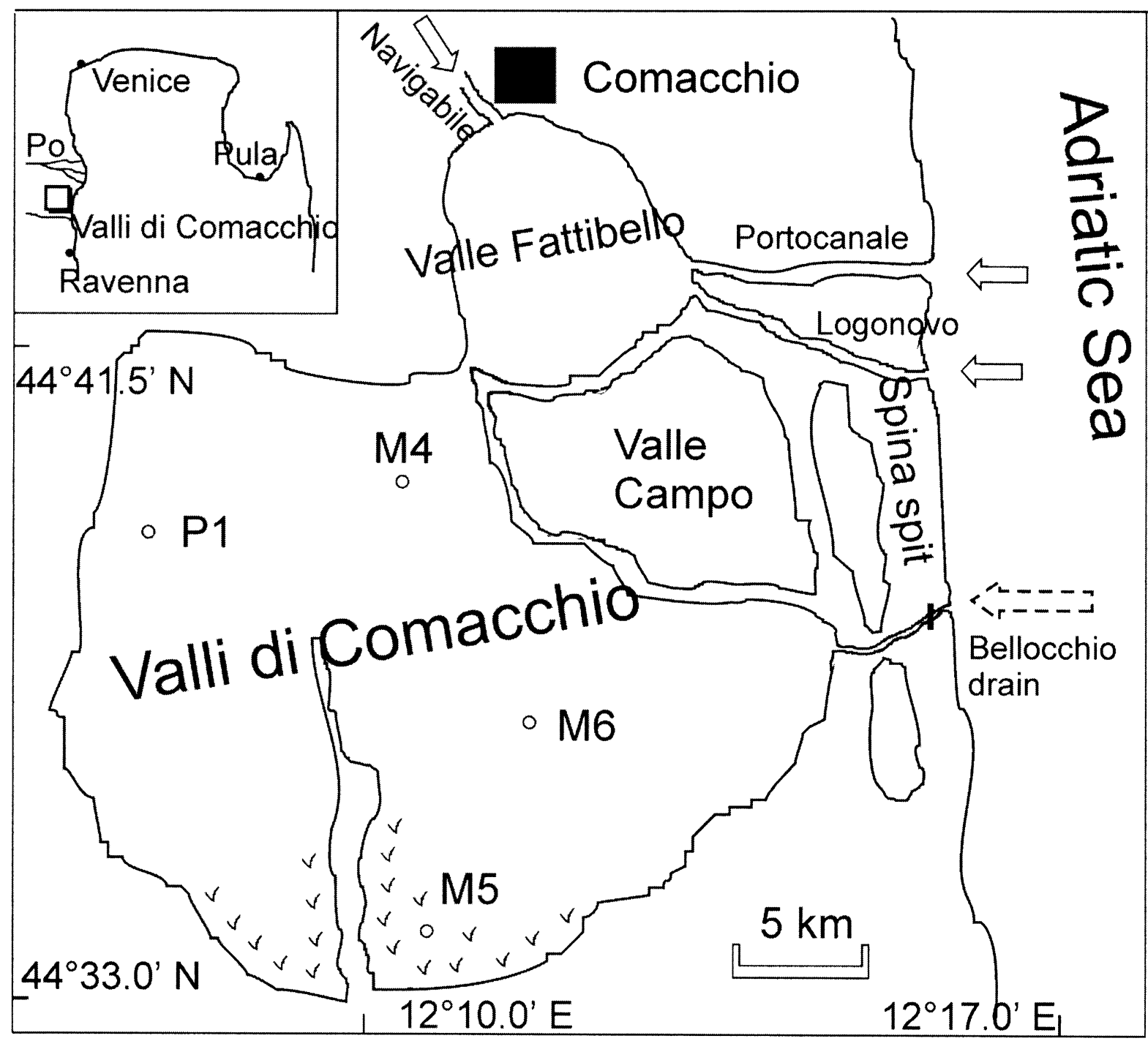

Fig. 1. Study station location (areas with Ruppia cirrhosa meadows are also reported).

discontinuity layer (RPDL) was also measured as the thickness of the brownish oxidized layer. Water parameters (temperature, salinity, dissolved oxygen, and chlorophyll-a) were measured at each site at fortnightly intervals (except for December) using an Idronaut Ocean Seven 316CTD multiparameter probe at about $20 \mathrm{~cm}$ above the bottom.

The 2001-macrobenthic communities were described through the number of taxa $(S)$, abundance $(N)$, richness (as Margalef's $d$ ), evenness (as Pielou's $J$ '), and diversity (as Shannon-Wiener's $H^{\prime}$ ). Community analysis was then performed using multivariate techniques both on the 2001 and the 1997-1998 data matrix. Formal significance tests for differences among 2001 sampling dates and sampling sites were performed using a crossed 2-way Anosim randomization/permutation test (Clarke and Warwick, 1994) from the Bray-Curtis similarity matrix (data fourth-root transformed). Data were then analyzed through non-metric multidimensional scaling (MDS, Clarke and Warwick, 1994), and species making the greatest contribution to dissimilarity among the four stations were investigated through
Simper analysis (Clarke and Warwick, 1994). The relationship between environmental variables and macrobenthic community structure was then explored by correlating euclidean distance similarity matrix of abiotic data (sediment plus water variables) with Bray-Curtis similarity matrix from benthic abundance data (BIOENV routine, Clarke and Warwick, 1994). For the 1997-1998 and 2001 combined data matrix, the 2-way Anosim randomization/permutation test was run, with stations nested into years. Simper analysis was performed to determine the contribution of individual species to total dissimilarity between years and stations. Multivariate analyzes were performed using the Primer ver. 5.0 software (Plymouth Marine Laboratory, UK).

\section{Results}

\subsection{Environmental data}

In Fig. 2 the temporal trend of water variables at the four sampling sites in 2001 is shown. Most parameters showed high seasonal variation because of the lagoonal nature of the 
sites. Chlorophyll-a concentration increased in spring, peaked in summer, then peaked again, only in the central area of the lagoon, in October. In Fig. 3 sedimentary variables at the four sampling dates are shown. Organic content was higher at P1 in January and, on the whole, lower concentrations were found at all stations in July. The microphytobenthic chlorophyll-a concentration peaked in April but it was fairly high all year round, showing variations due to the patchy distribution of benthic microalgae. The minimum depth of RPDL was registered at P1 in July, but, at our sampling dates, an aerobic layer was always present.

\subsection{The 2001 communities}

In 2001, a total of 52 taxa, belonging to six phyla, was recovered and identified. The most diversified group was Annelida, which constituted $76 \%$ of total macrofauna, followed by Arthropoda (17.1\%), Mollusca (6.1\%), and other minor groups (Cnidaria, Turbellaria, and Nemertea: $0.8 \%$ ). Nine of the species collected accounted for $83.4 \%$ of total abundance. This group comprised opportunistic species typical of brackish environments, such as Oligochaeta (two unidentified species, $24 \%$ of total abundance), Corophium insidosum (15.3\%), Neanthes succinea (13.7\%), Armandia cirrhosa (7.6\%), Polydora ciliata (7.4\%), Heteromastus filiformis (6.2\%), Hydrobia sp. (5.3\%), and Hydroides dianthus $(3.9 \%)$. Of great importance was the discovery at one site (M6) of the mussel Musculista senhousia, even if with low abundance $(0.1 \%)$. The 2-way crossed Anosim test among the four stations and the four sampling periods showed significant differences for these two factors Table 1). The highest $r$-values in pairwise tests were observed when comparing P1 with M4 and M5, and M5 with M6. Moreover, differences were observed between all the four dates. In Fig. 4 the MDS
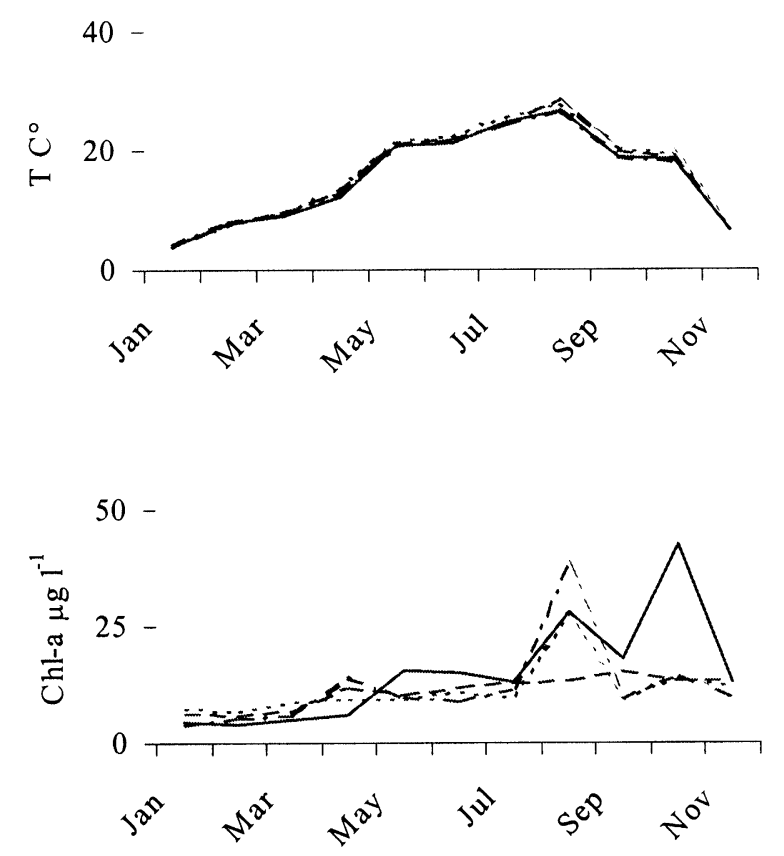

ordination plot, with superimposed groups generated by cluster analysis (UPGMA on Bray-Curtis similarity matrix), is shown, with sample points arranged along the horizontal axis and segregated into two major groups: one comprising all P1 points plus M4 and M6 at two dates (January and July), and another comprising all M5 points plus M4 and M6 at the two other dates (April and October). An analysis of the contribution from individual species abundance to the average Bray-Curtis dissimilarity between the four stations using Simper, showed that differences were mainly due to the average higher proportion of $A$. cirrhosa, H. filiformis, Capitellidae sp. 1 and Oligochaeta sp. 1 at M5. Species breakdown of similarities for each station showed that while at P1 6 species contributed for $>90 \%$ of this similarity, at M4, M5 and M6 they were 13, 14 and 9, respectively Table 2p. In Fig. 5 univariate indices at the four sampling sites are shown. On the whole, M4 and M5 exhibited the most structured communities, while P1 and M6 were more impoverished. The results of BIOENV analysis showed weak correlations between environmental and biotic data: the highest rank correlation $(r=0.258)$ occurred with a group of three variables, i.e. microphytobenthic chlorophyll-a, depth of RPD, and temperature; the second best correlation $(r=0.244)$ occurred with the same three variables plus sedimentary organic content.

\subsection{Comparison of the benthic community structure between 1997-1998 and 2001}

In 1997-1998, a total of 37 benthic taxa were recovered and identified (Mistri et al., 2000). While merging the 1997-1998 and 2001 data sets, to avoid the possibility that differences in community structure were due to the different taxonomic level of resolution of some faunal groups, taxa
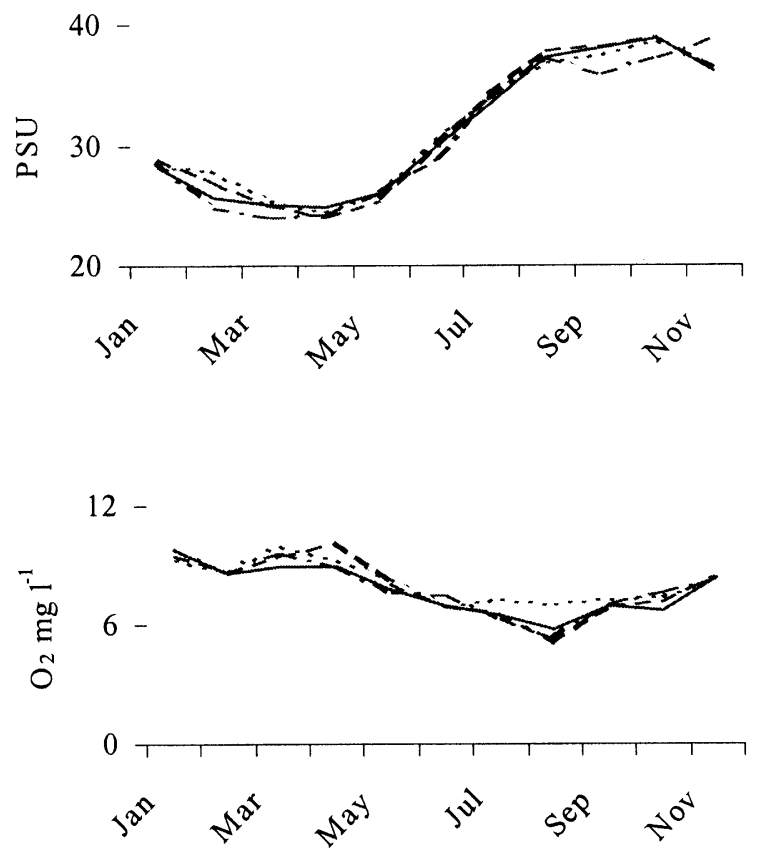

Fig. 2. Trends of water parameters at the four study stations in 2001 (lines: broken-long, P1; broken-short, M4; broken-long and short, M5; continuous, M6). 

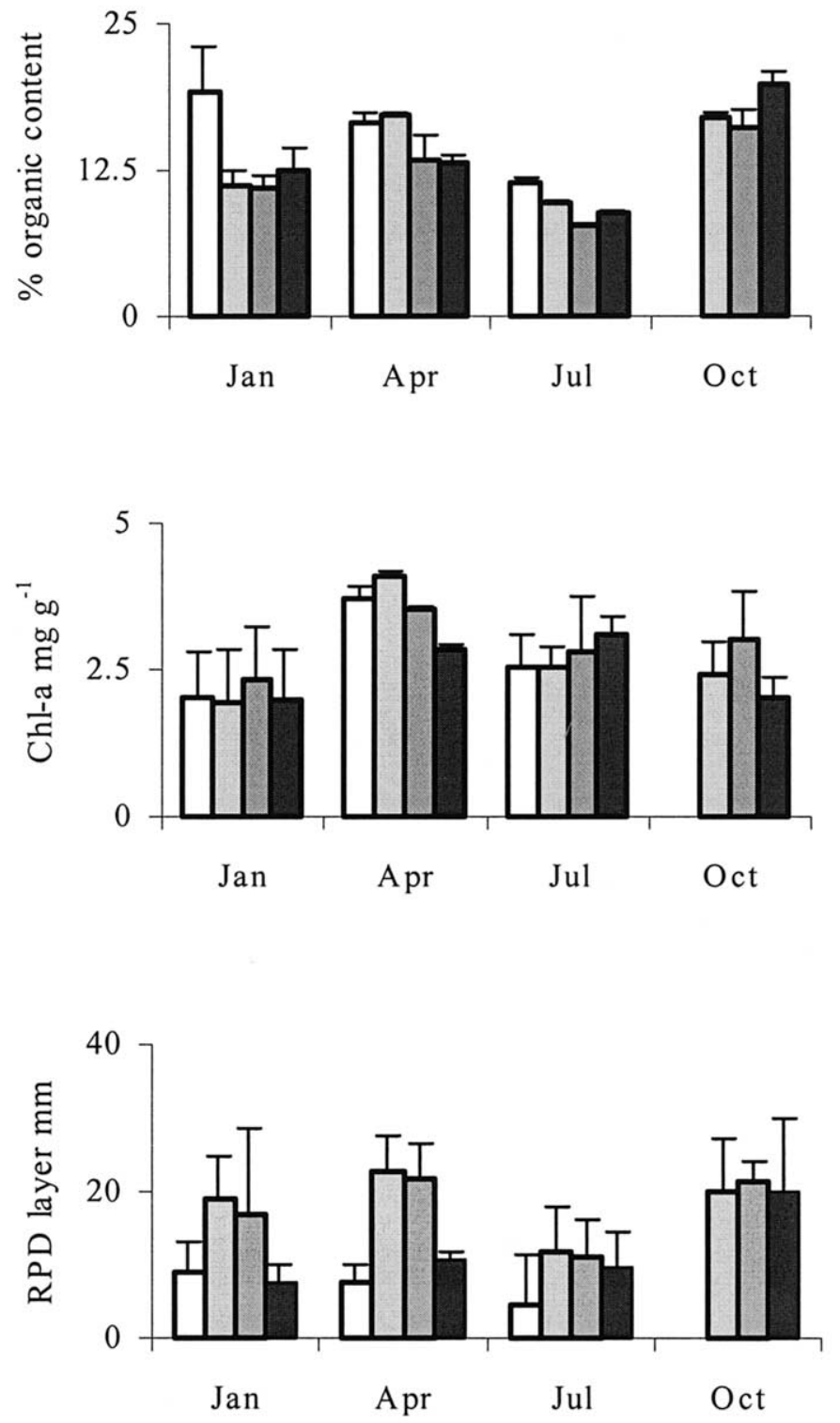

Fig. 3. Sedimentary parameters (with SD) at the four study stations in 2001 (P1, white; M4, light gray; M5, dark gray; M6, black).

Table 1

Results of global and pairwise test (global $r$ and $P$ ) from 2-way crossed Anosim for differences among sites and dates in 2001

\begin{tabular}{|c|c|c|c|c|c|}
\hline & \multicolumn{2}{|c|}{ Global test } & \multicolumn{3}{|c|}{ Pairwise test } \\
\hline & $r$ & $P(\%)$ & Groups & $R$ & $P(\%)$ \\
\hline \multirow[t]{6}{*}{ Between sites } & 0.53 & 0.1 & P1-M4 & 0.67 & 0.1 \\
\hline & & & P1-M5 & 0.78 & 0.1 \\
\hline & & & P1-M6 & 0.37 & 0.1 \\
\hline & & & M4-M5 & 0.5 & 0.2 \\
\hline & & & M4-M6 & 0.35 & 1.0 \\
\hline & & & M4-M6 & 0.63 & 0.1 \\
\hline \multirow[t]{6}{*}{ Between dates } & 0.57 & 0.1 & January-April & 0.72 & 0.1 \\
\hline & & & January-June & 0.51 & 0.3 \\
\hline & & & January-October & 0.32 & 3.4 \\
\hline & & & April-June & 0.79 & 0.1 \\
\hline & & & April-October & 0.62 & 0.1 \\
\hline & & & June-October & 0.55 & 0.1 \\
\hline
\end{tabular}




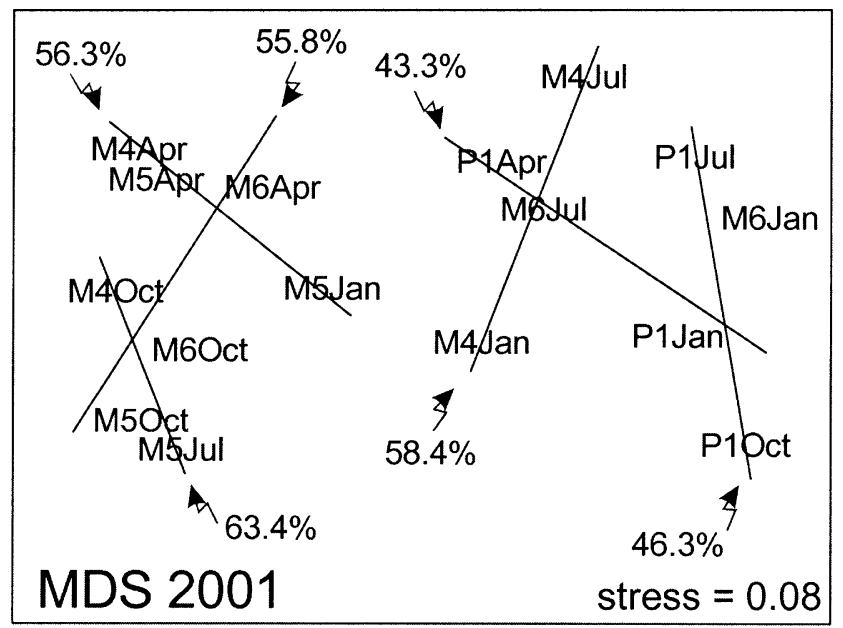

Fig. 4. Non-metric multidimensional scaling ordination plot derived from fourth root transformed abundance data. Superimposed lines join points clustered by classification analysis (similarity levels are also given).

that in 2001 were identified at lower taxonomic level were combined at the same level used in 1997-1998 (e.g. abundance of Syllis gracilis, Syllides edentulus, and Grubeosyllis clavata were summed and reported as Syllidae, as in the 1997-1998 data set). After the reduction, the 2001 data set resulted made up by 42 taxa. The nested 2-way Anosim test among stations and between years (1997-1998 and 2001) showed significant differences for both factors (stations: global $r=0.326$, significance level $=0.1 \%$; years: global $r=0.917$, significance level $=2.9 \%$ ). On the 1997-1998 data set, species breakdown of similarities for each station (simper analysis) showed that only four species contributed for $>90 \%$ of similarity at M6, while at P1, M4, and M5 species were 5, 10 and 14, respectively. Average dissimilarity between each station in the two periods on the basis of the contribution of faunal groups, revealed that at M6
(1997-1998 vs. 2001) this dissimilarity was highest (76.1\%), followed by M4 and P1 (62.9 and 62.7\%, respectively); the lowest dissimilarity was detected at M5 (52\% only). Generally speaking, at each station the macrobenthic community sampled in 2001, compared to 1997-1998, had higher abundance and more species. Such a different faunal assemblage at M6 was due to increased abundance of species already present at the station (i.e. Oligochaeta, Capitella capitata, Neanthes succinea, H. filiformis, Hydroides dianthus, and Corophium spp.), but also to the finding of eight new taxa ( $A$. cirrhosa, Polydora ciliata, Streblospio shrubsolii, Spio decoratus, Syllidae spp., Cirratulidae spp., Actiniaria sp., and Serpulidae spp; Simper analysis) that in 1997-1998 were absent at that site.

\section{Conclusion}

Environmental fluctuations may act as disturbance preventing natural communities from developing to persistent stable states (Koutsoubas et al., 2000). Faunal assemblages, however, may exhibit dynamic equilibria where attributes of populations and communities change rapidly to track environmental variations (Beukema, 1992). In the Valli di Comacchio, environmental parameters showed a high variability throughout 2001, with a very strong seasonal component. This is possibly due to the combined effects of the high evaporation and the reduced water exchange, but other factors, as will be discussed later, probably played an important role in determining the overall environmental quality. Lower values of community descriptors indicated that, at P1 and M6, the benthic community was disturbed. M6 was traditionally the most impaired site in the lagoon, because of confinement and vicinity to the effluent pipe of aquaculture plants, but from winter 2001 onwards its benthic assemblages

Table 2

Simper analysis: average abundance of species contributing to similarity (cut-off: $90 \%$ ) at each site in 2001

\begin{tabular}{|c|c|c|c|c|c|c|c|}
\hline Species & $\mathrm{P} 1$ & & M4 & & M5 & & M6 \\
\hline Nemertea sp. & - & & - & & 46.3 & & - \\
\hline Hydrobia sp. & - & & 539.6 & $<$ & 169.6 & $<$ & 773.9 \\
\hline Cerastoderma glaucum & - & & - & & - & & 107.9 \\
\hline Polydora ciliata & - & & - & & 141.8 & & - \\
\hline Streblospio shrubsolii & 92.3 & $>$ & 24.7 & & - & & - \\
\hline Cirriformia tentaculata & - & & 225.1 & $>$ & 74 & & - \\
\hline Capitellidae sp. 1 & 43.2 & $<$ & 194.3 & $<$ & 1316.6 & $>$ & 610.5 \\
\hline Heteromastus filiformis & 18.5 & $<$ & 144.9 & $<$ & 1233.3 & $>$ & 558.1 \\
\hline Armandia cirrhosa & 391.6 & $>$ & 299.1 & $<$ & 1486.2 & $>$ & 200.4 \\
\hline Ophiodromus pallidus & - & & - & & 200.4 & & - \\
\hline Syllis gracilis & - & & 154.2 & $>$ & 27.8 & & - \\
\hline Syllides edentulus & - & & - & & 160.3 & & - \\
\hline Neanthes succinea & 1060.5 & $<$ & 1430.7 & $>$ & 925 & $>$ & 872.6 \\
\hline Eunice vittata & - & & 15.4 & & - & & - \\
\hline Hydroides dianthus & - & & - & & 962 & $>$ & 154.2 \\
\hline Oligochaeta sp. 1 & 129.5 & $<$ & 2226.2 & $<$ & 2500.6 & $>$ & 863.3 \\
\hline Oligochaeta sp. 2 & - & & 838.7 & & - & & - \\
\hline Microdeutopus gryllotalpa & - & & 12.3 & & - & & - \\
\hline Corophium insidiosum & - & & 2620.8 & $>$ & 650.6 & $<$ & 1535.5 \\
\hline
\end{tabular}



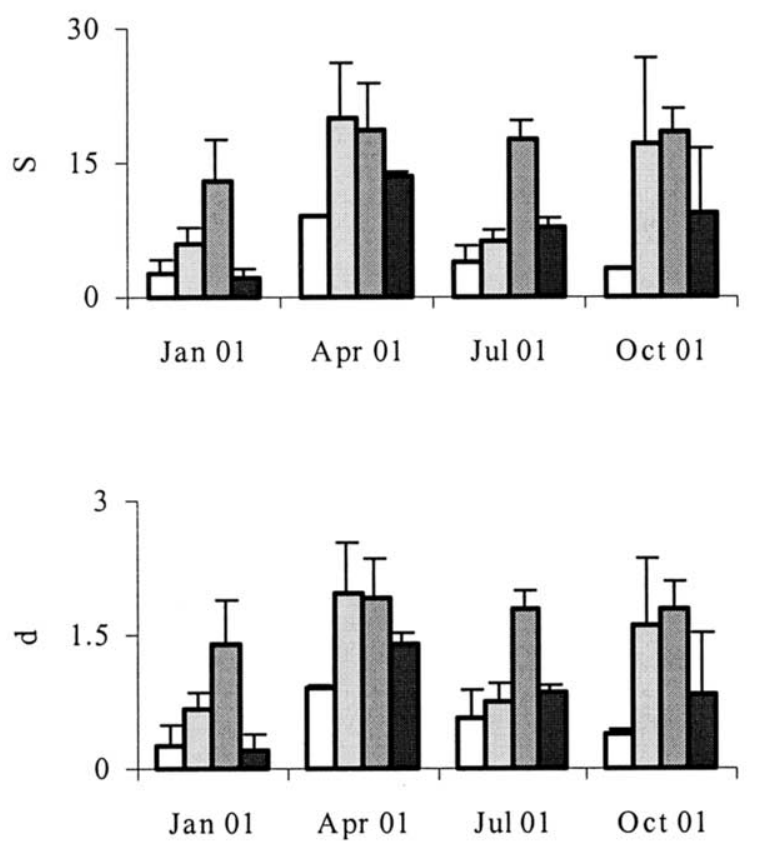
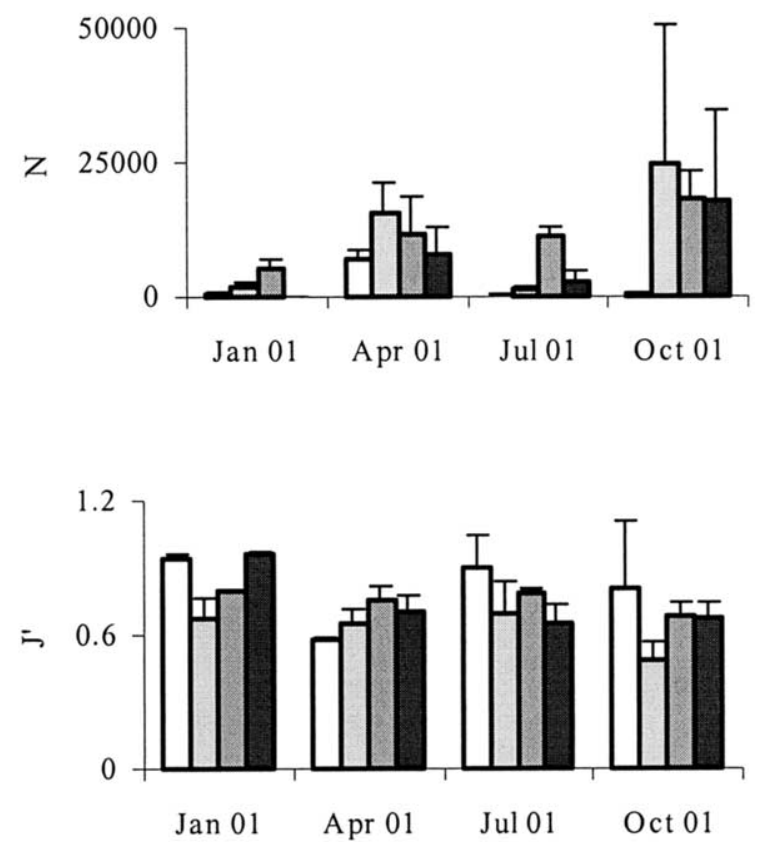

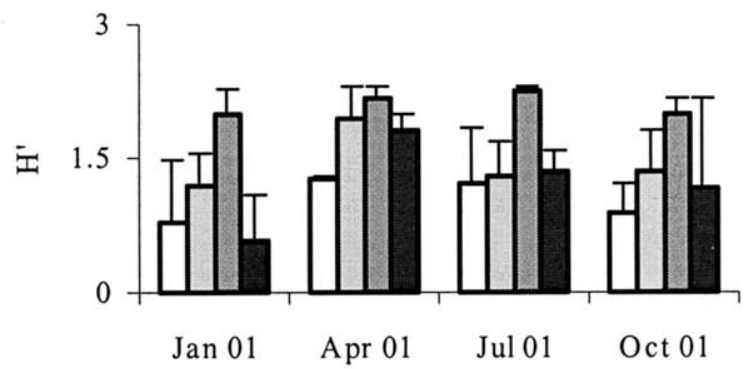

Fig. 5. Community descriptive indices in 2001 (station codes as in Fig. 3).

greatly benefited from the increased flushing through the Bellocchio drain. Conversely, in 2001 P1 had become the most confined sampling site: from summer onwards, an ancient submerged dike almost resurfaced (thus hindering part of October's sampling program at that site) because of a modified hydraulic management of the westernmost part of the lagoon. On the other hand, the communities at M4 and, particularly, M5 were the most well structured. Of these, the former probably benefited from continuous vivification due to tidal marine waters, while the latter confirmed the beneficial role that the presence of even scarcely vegetated areas play on benthic faunal assemblages (Lewis, 1984). On the basis of the taxa collected, differences in faunistic distribution among the four stations were recognized, although much less marked than in previous research (Mistri et al., 2000).

The comparison of the macrobenthic structure between 1997-1998 and 2001 showed significant differences of species composition and community structure especially in the central area of the lagoon, where a clear recovery of benthic assemblages was observed in 2001 compared to 1997-1998. Recovery processes may vary considerably depending on the type of stressor and the spatial and temporal scales of the disturbance. It is well known (Zajac and Whitlatch, 1982) that benthic communities generally respond rapidly to environmental changes, although slow macrobenthic recovery processes are quite common. For example, Moore and Rodger (1991) found still signs of disturbance in macrobenthic assemblages from the Firth of Clyde (Scotland) 11 years after the cessation of sewage disposal. Rosenberg (1976) found that a site in a Swedish fjord enriched by discharge from a pulp mill took 8 years to recover after the pollution abatement. In the Valli di Comacchio, organic enrichment from aquaculture plants ceased in 1990, but signs of disturbance in the macrobenthic community, particularly in the central area, were still detectable after 8 years (Mistri et al., 2000). In 2001, benthic assemblages at most of our sampling sites had greatly increased in complexity. The recovery of macrobenthic communities was mainly due to opportunistic taxa, which colonized above all the central area of the lagoon (M6), but the presence in the same area of Cerastoderma glaucum and Musculista senhousia probably testified to an improvement in overall environmental conditions. Moreover, this was the first record of the Indo-Pacific species M. senhousia, which recently spread in the Sacca di 
Goro (Mistri, 2002b), in the Valli di Comacchio: planktonic larvae probably were conveyed through Bellocchio drain. Analysis of the community structural parameters confirmed such an improvement in environmental conditions, with an increase in number of species, abundance and diversity, especially in the central area, where very few taxa and individuals were collected in 1997-1998. It is reported that the spatial distribution of organisms in the Valli, at least until 2000, was under the control of factors linked to organic enrichment of the sediments (Mistri et al., 2002). In 2001, the relationships between sedimentary organic content, microphytobenthic chlorophyll-a and biotic data provided evidence that trophic status and its dynamics in the lagoon was crucial in determining species distribution among the different lagoonal areas. Organically enriched sediments, as those of the Valli, usually developed summer anoxia because of their high oxygen demand (Mistri et al., 2002). During our sampling campaigns, however, we did not find trace of anoxic crises, as we did in the previous years, and an oxidized layer was always recorded in sediment cores, independently from the season and the site.

Finally, the benthic community thriving in the southern marginal area (M5) exhibited some distinct attributes of persistence, such as the constancy of system parameters (number of species, taxonomic composition, population size) over time. We may hypothesize that marginal and vegetated areas of the Valli acted as refuge habitats for macrobenthic biodiversity, sustaining diversified and well structured communities, even when the habitat in central area of the lagoon was subjected to destructuring factors (anoxia, sedimentary release of sulfide and ammonia) and its communities were extremely impoverished. Then, following an improvement of habitat conditions, the $r$-selected group of species of benthic assemblages from marginal areas was able to rapidly recolonize the inner part of the lagoon.

Since late 1996, when the monitoring program in the Valli di Comacchio began, this is the first report of a macrofaunal recovery, after the collapse of benthic assemblages in the early 1990 (Sorokin et al., 1996). The recovery of macrobenthos in the innermost area of the Valli seems to emphasize that the pattern of community displacement and succession in lagoonal species-poor systems follows the generalizations proposed for marine ecosystems by Pearson and Rosenberg (1978). However, this pattern may be slowed or altered by secondary disturbances, like hydrodynamic processes (e.g. the increased confinement of the westernmost part of the Valli), or the release of toxic substances from anoxic sediments, which may be dependent on the nature and kind of the initial stressors. In anthropogenically impacted environments, the succession towards recovery is not necessary simple and monotonic, but, because of secondary disturbances, may proceed through progressions and regressions (Karakassis et al., 1999). A similar pattern of benthic recovery was observed by Lardicci et al. (2001) in the dystrophic Orbetello lagoon, Italy. In Mediterranean lagoons, the lack of long-term studies on the dynamics of benthic assemblages makes it difficult to assess the time needed for the recovery of such systems after severe disturbance events: in the Valli di Comacchio, signs of amelioration were detected after 11 years from cessation of aquaculture activities. Whether this apparent recovery will proceed directionally or pass through progressions and regressions, is a matter that warrants further studies.

\section{Acknowledgements}

This study was partially supported by the Italian Ministry of Instruction, University and Research (MIUR, COFIN99), and partially by the Regional Agency for Environmental Protection through a grant from the Azienda Speciale Valli di Comacchio. The manuscript benefited from comments given by three anonymous reviewers.

\section{References}

Beukema, J.J., 1992. Expected changes in the Wadden Sea benthos in a warmer world: lessons from periods with mild winters. Neth. J. Sea Res. 30, 73-79

Clarke, K.R., Warwick, R.M., 1994. Changes in marine communities: an approach to statistical analysis and interpretation. Plymouth Marine Laboratory, Plymouth.

Colombo, G., Ceccherelli, V.U., Gaiani, V., 1977. Biomassa macrobentonica delle Valli di Comacchio. Atti IX S.I.B.M., 199-211.

Guelorget, O., Perthuisot, J.P., 1983. Le domain paralique. Expression géologiques, biologiques et économiques du confinment. Travaux du Laboratoire de Géologie, Ecole Normale Supérieure de Paris 16.

Karakassis, I., Hatziyanni, E., Tsapakis, M., Plaiti, W., 1999. Benthic recovery following cessation of fish farming: a series of successes and catastrophes. Mar. Ecol. Prog. Ser. 184, 205-218.

Koutsoubas, D., Dounas, G., Arvanitidis, C., Kornilios, S., Petihakis, G., Triantafyllou, G., Eleftheriou, A., 2000. Macrobenthic community structure and disturbance assessment in Gialova Lagoon, Ionian Sea. ICES J. Mar. Sci. 57, 1472-1480.

Lardicci, C., Como, S., Corti, S., Rossi, F., 2001. Recovery of the macrozoobenthic community after severe dystrophic crises in a Mediterranean coastal lagoon (Orbetello Italy). Mar. Poll. Bull. 42, 202-214.

Le Bris, H., Glémarec, M., 1996. Marine and brackish ecosystems of Southe Brittany (Lorient and Vilaine Bays) with particular reference to the effect of the turbidity maxima. Estuar. Coast. Shelf Sci. 42, 737-753.

Lewis, F.G., 1984. Distribution of macrobenthic crustacean associated with Thalassia, Halodule and bare sand substrata. Mar. Ecol. Prog. Ser. 19, 101-113.

Lorenzen, C., Jeffrey, J., 1980. Determination of chlorophyll in seawater. Technical Paper. Mar. Sci. (UNESCO) 35, 1-20.

Mistri, M., 2002a. Persistence of benthic communities: a case study from the Valli di Comacchio, a Northern Adriatic lagoonal ecosystem (Italy). ICES J. Mar. Sci. 59, 314-322.

Mistri, M., 2002b. Ecological characteristics of the invasive Asian date mussel, Musculista senhousia, in the Sacca di Goro (Adriatic Sea, Italy). Estuaries 25, 431-440.

Mistri, M., Fano, E.A., Ghion, F., Rossi, R., 2002. Disturbance and community pattern of Polychaetes inhabiting Valle Magnavacca (Valli di Comacchio, Northern Adriatic Sea, Italy). P.S.Z.N.I: Mar. Ecol. 23, 31-49.

Mistri, M., Fano, E.A., Rossi, R., 2001. Redundancy of macrobenthos from lagoonal habitats in the Adriatic Sea. Mar. Ecol. Prog. Ser. 215, 289-296. 
Mistri, M., Fano, E.A., Rossi, G., Caselli, K., Rossi, R., 2000. Variability in macrobenthos communities in the Valli di Comacchio. Northern Italy, a hypereutrophized lagoonal ecosystem. Estuar. Coast. Shelf Sci. 51, 599-611.

Moore, D.C., Rodger, G.K., 1991. Recovery of a sewage sludge dumping ground. II. Macrobenthic community. Mar. Ecol. Prog. Ser. 75, 301-308.

Pearson, T.H., Rosenberg, R., 1978. Macrobenthic succession in relation to organic enrichment and pollution of the marine environment. Oceanogr. Mar. Biol. Annu. Rev. 16, 229-311.
Rosenberg, R., 1976. Succession in benthic macrofauna in a Swedish fjord subsequent to the closure of a sulphite pulp mill. Oikos 24, 244-258.

Sorokin, I.Yu, Sorokin, P.Yu, Gnes, A., 1996. Structure and functioning of the anthropogenically transformed Comacchio lagoonal ecosystem (Ferrara, Italy). Mar. Ecol. Prog. Ser. 133, 57-71.

Zajac, R.N., Whitlatch, R.B., 1982. Responses of estuarine infauna to disturbance. II. Spatial and temporal variation of succession. Mar. Ecol. Prog. Ser. 10, 15-27. 